\title{
VZTAH AKADEMICKÉ MARNOSTI A VÝSLEDKŮ ŽÁKŮ: RŮZNÉ MECHANISMY PRO MATEMATIKU A ČTENÁŘSKOU GRAMOTNOST ${ }^{1}$
}

\section{THE RELATIONSHIP BETWEEN ACADEMIC FUTILITY AND STUDENT ACHIEVEMENT: DIFFERENT MECHANISMS FOR MATHEMATICS AND READING LITERACY}

\author{
JANA STRAKOVÁ, \\ JAROSLAVA SIMONOVÁ
}

\begin{abstract}
Abstrakt
Výzkumy ukazuji, že žáci odborných středoškolských programu maji horši výsledky než žáci všeobecně vzdèlávacich programi i tehdy, když zoblednime jejich vstupni výsledky a rodinné zázememi. Možné príčiny tohoto jevu výzkumníci spatruji v klimatu školy. V této stati je klima školy operacionalizováno prostrednictvím kultury akademické marnosti. Zkoumáme, zda pocit akademické marnosti ovlivñuje výsledky

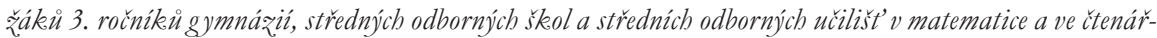
ské gramotnosti, zoblednime-li jejich rodinné zázemi a vstupni vědomosti. Analýza využivajicí viceúrovnové modelováni v programu MPlus je provedena na souboru 2846 žákì ze 143 trúd v 79 školách, kteři byli testováni a dotaz̧ováni na počátku středoškolskébo studia a potom opèt v polovinè 3. ročníku. Výsledky potvrzují vliv pocitu akeademické marnosti na sledované výsledky a ukazuji mirné odlišnosti v jeho uplatnénív obou disciplinách.
\end{abstract}

Klíčová slova

stredoškolské vadèlávání, pocit akademické marnosti, výsledky vz̨èlávání, longitudinálni studie, strukturni víceúrovnové modelování

Text je výstupem řešení projektu GA ČR 18-19056S. Autoři děkují recenzentům za cenné připomínky. 


\begin{abstract}
Research has shown that students in vocational secondary school programs have worse results than students in general-education programs do, even when their initial results and family background are taken into account. Researchers have noted possible causes of this phenomenon in the school climate. In this article, the school climate is operationalized through a culture of academic futility. We examine whether the feeling of academic futility affects the performance in mathematics and reading literacy of third-year students at grammar schools, secondary vocational schools, and apprenticeship schools, taking into account their family background and initial knowledge. The analysis used multi-level modeling in MPlus and was performed on a set of 2,846 students from 143 classes in 79 schools who were administered tests and questionnaires at the beginning of secondary school and then again in the middle of their third year. The results confirm the effect of academic futility on student achievement and show slight differences in its effect between the two subjects.
\end{abstract}

\title{
Keywords
}

upper secondary education, academic futility, academic achievement, longitudinal study, structural equation modeling

\section{Úvod}

Česká republika je mezi zeměmi OECD po Rakousku a Slovensku zemí s tř̌etím nejvyšším podílem žáků v odborném vzdělávání (OECD, 2019). S odbornou kvalifikací zde odcházejí ze středoškolského studia téměř tři čtvrtiny jeho absolventů. Data z mezinárodního výzkumu PISA, který probíhá v prvních ročnících stř̌edních škol ${ }^{2}$, ukazují, že je velký rozdíl ve složení žáků navštěvujících gymnaziální a odborné programy z hlediska jejich rodinného zázemí i výsledků vzdělávání na konci 1. ročníku (např. Blažek et al., 2019). V ČR neprobíhá žádné testování, které by umožnilo srovnat vědomosti a dovednosti všech žáků na výstupu ze středoškolského vzdělávání. Srovnatelnou informaci máme pravidelně pouze ohledně žáků maturitních oborů v podobě výsledků maturitní zkoušky, které ukazují velké rozdíly ve výstupních vědomostech a dovednostech žáků odborných a gymnaziálních oborů. Dostupné výsledky z mezinárodních výzkumů, které prováděly měření v populaci osmnáctiletých (výzkum matematického a prŕírodovědného vzdělávání TIMSS v roce 1995, výzkum občanského vzdělávání CIVED v roce 1998 i výzkum vědomostí a dovedností dospělých PIAAC v roce 2012), ukazují velké rozdíly u žáků jednotlivých programů na výstupu ze středo-

2 Výzkum PISA je zacílen na patnáctileté žáky, výběr se řídí podle data narození. Polovina těchto žáků v ČR navštěvuje poslední ročníky povinného vzdělávání, polovina navštěvuje první ročníky středních škol. 
školského vzdělání nejen ve vědomostech a dovednostech, ale rovněž v postojích (např. Dzúrová et al., 2015; Straková, 2015; Straková \& Simonová, 2013; Straková et al., 1998).

Velké rozdíly mezi jednotlivými středoškolskými programy jsou v ČR vnímány jako přirozené. Vycházíme z toho, že programy směřují k odlišným vzdělávacím cílům a že si každý žák vybere podle svého zájmu a schopností program, který mu bude nejlépe vyhovovat, s vědomím důsledků této volby z hlediska př́ípravy pro další osobní i profesní život. Situace je však ve skutečnosti složitější. Mezi středoškolskými programy (gymnaziálním, středním odborným s maturitou a středním odborným bez maturity) jsou v České republice opravdu velké rozdíly v cílech vzdělávání, kurikulu, a tedy i nárocích kladených na žáky. Jednotlivé obory se liší z hlediska učebního prostředí, které je dáno např. vybavením škol, výskytem kázeňských problémů, kvalifikovaností učitelů a podobně. Obory jsou velmi specializované (máme více než 300 oborů), přestupy mezi jednotlivými programy jsou minimální. Volba oboru je tedy z hlediska budoucí př́ípravy mladého člověka velmi důležitá (např. Hlad’o \& Šlapalová, 2019). Ta je ovšem silně ovlivněna rodinným zázemím (nap̌r. Hlad'o, 2010; Hlad'o \& Balcar, 2012; Hlad’o \& Ježek, 2018). Máme doklady o tom, že žáci z rodin s horším socioekonomickým statusem nastupují do odborného a zejména do odborného vzdělávání bez maturity častěji, než odpovídá jejich vzdělávacím výsledkům a kognitivním předpokladům (napr. Straková, 2015). Zároveň jsme svědky úsilí tvůrců vzdělávacích politik motivovat žáky na konci povinné školní docházky k nástupu do odborných oborů bez dostatečné reflexe, zda je pro ně tato volba z dlouhodobého hlediska výhodná. ${ }^{3} \mathrm{~V}$ této souvislosti považujeme za důležité zdůraznit, že Česká republika je jednou z mála evropských zemí, ve kterých odborná kvalifikace nezvyšuje pravděpodobnost zaměstnanosti. ${ }^{4}$

3 Např́iklad Dlouhodobý záměr vzdělávání a rozvoje vzdělávací soustavy ČR na období 2011-2015 si kladl explicitní cíl získat minimálně $32 \%$ absolventů povinného vzdělávání pro nematuritní odborné obory a zachovat podíl gymnaziálních studentů na stávající úrovni 25-32\%. Snahou získat mladé lidi pro odborné vzdělávání byly motivovány programy polytechnické výchovy v předškolním a povinném vzdělávání uvedené v Dlouhodobém záměru vzdělávání a rozvoje vzdělávací soustavy ČR na období 2016-2020. Touto snahou byl motivován též záměr zavést tzv. cut-off score, tedy stanovit minimální výsledek v přijímací zkoušce, kterého musí dosáhnout každý uchazeč o maturitní studium (viz např. https://www.eduin.cz/clanky/duel-zijete-v-minulem-stoleti-cut-off-score-vyrobi-z-ucnu-nezamestnane/).

4 https://ec.europa.eu/info/sites/info/files/european-semester_thematic-factsheet_ skills-for-labour-market_en_0.pdf 
V této situaci nám připadá důležité zjistit více o tom, jak volba středoškolského programu ovlivňuje výsledky vzdělávání a jakými mechanismy. Zajímá nás, jak jsou výsledky žáků ve 3. ročníku středoškolského studia, kdy část z nich studium opouští, ovlivněny vzdělávacím programem, rodinným zázemím, vstupními znalostmi a školním klimatem operacionalizovaným jako kultura akademické marnosti. Zkoumáme výsledky v matematice, která je hodně specifická pro jednotlivé programy, a ve čtenářské gramotnosti, která by naopak měla tvořit přirozenou výbavu každého absolventa středoškolského studia.

\section{Odborné vzdělávání a školní klima v zahraničních výzkumech}

\section{Poznatky z výzkumù odborného vzudèláváni}

Odborné vzdělávání se těší ve vyspělých zemích značné podpoře, nebot’ dle mínění mnohých tvůrců vzdělávacích politik představuje řešení dvou závažných problémů: nezaměstnanosti absolventů a nedostatku technické pracovní síly na trhu práce (např. Eichhorst et al., 2015). Výzkum nicméně ukazuje, že i když v řadě vzdělávacích systémů je přechod absolventů odborných škol na pracovní trh skutečně plynulejší, v pozdějších etapách pracovní kariéry mají úzce specializovaní absolventi odborných oborů ve srovnání s těmi, kterým se dostalo širšího všeobecného vzdělávání, situaci naopak značně ztíženu. Je pro ně obtížnější reagovat na měnící se požadavky trhu práce osvojováním si nových dovedností nebo změnou profese (Dockx \& De Fraine, 2018; Hampf \& Wößmann, 2016; Hanushek et al., 2011).

Zároveň existují doklady o tom, že samotné studium v odborném vzdělávání může žáky negativně ovlivnit, nebot' může mít negativní dopady na jejich výsledky a studijní motivaci. Rozdíly, které existují mezi žáky různých programů na vstupu do středoškolského studia, mohou být v průběhu studia dále posilovány. Např́. Hanushek a Wößmann (2006) ukázali, že žáci v odborných programech dosahují horších výsledků a častěji ukončují studium předčasně než žáci ve všeobecných vzdělávacích programech i po zohlednění rodinného zázemí a výsledků při vstupu do střední školy.

Zde se pravděpodobně uplatňují negativní aspekty diferenciace, které jsou známy z rozsáhlých výzkumů na všech stupních škol. V první řadě ukazují, že rozdělování žáků do jednotlivých větví se neřídí zdaleka jen kognitivními předpoklady a zájmy žáků, ale závisí na jejich rodinném zázemí. Nevýběrové programy mají vyšší zastoupení žáků z rodin s nižším socioekonomickým statusem (např. Alpert \& Bechar, 2008; Maaz et al., 2008; Rubin \& Noguera, 2004). Výzkumy dále poukazují na zcela odlišné školní zkušenosti žáků, kdy jsou v různých programech vzhledem k žákům ze strany školy komunikována odlišná očekávání, žáci jsou vyučováni různě kvalifikovanými uči- 
teli, programy se odlišují i kurikulem a stanovenými cíli vzdělávání, liší se i kvalita pomůcek a vybavení škol (Hanushek \& Wößmann, 2006; Kelly \& Carbonaro, 2012; Oakes, 2005; Page, 1991; Rubin \& Noguera, 2004, Van de Werfhorst \& Mijs, 2010). V náročnějších programech je kladen důraz na řešení problémů a rozvoj myšlenkových dovedností, zatímco v méně náročných programech je kladen důraz spíše na memorování a udržení kázně (napr. Kunter \& Baumert, 2006; Van Houtte, 2004). Proto je důležité při studiu rozdílů ve výsledcích zvažovat rozdíly ve školním kontextu a snažit se lépe porozumět vztahu mezi tímto kontextem a různými typy kognitivních i nekognitivních vzdělávacích výsledků.

\section{Kultura akademické marnosti jako charakteristika školníbo klimatu}

Školní kontext je často operacionalizován jako školní klima, které se skládá z několika dimenzí, přičemž tyto dimenze se u jednotlivých autorů mírně odlišují (např. Thapa et al., 2013; Wang \& Degol, 2016; Zullig et al., 2010). V českém kontextu Grecmanová (2008) a Grecmanová et al. (2012) strukturovala školní klima do školní kultury, sociálních vztahů, osobní a ekologické organizace.

Jednou ze složek školního klimatu, respektive školní kultury, u níž byla shledána souvislost s výsledky vzdělávání, je pocit akademické marnosti. Koncept akademické marnosti byl poprvé navržen Brookoverem a Schneiderem (1975) s cílem nalézt faktory, které charakterizují školní prostř́edí a mají významný vliv na výsledky žáků i po zohlednění složení žáků školy. Brookover a Schneider (1975) identifikovali v rámci školního klimatu, tak jak jej chápali pro účely svého výzkumu, pět dimenzí, přičemž pocit akademické marnosti se ukázal ze všech dimenzí jako nejvlivnější.

Koncept akademické marnosti je v jejich chápání velmi podobný konceptu kontroly nad vlastním životem (sense of control), který používali Coleman et al. (1966). Rozdíl spočívá v tom, že pocit akademické marnosti se explicitně vztahuje ke škole. Tedy charakterizuje víru žáka v to, že je schopen ovlivnit své fungování v rámci vzdělávacího systému. Vysoký pocit akademické marnosti znamená, že žák věří, že nemůže nikterak ovlivnit svůj školní úspěch. Původní koncept akademické marnosti, který Brookover a Schneider (1975) používali pro výzkum rozdílů ve výsledcích žáků jednotlivých škol v rámci povinného vzdělávání, měl tři dimenze: první se týkala pocitu akademické marnosti vnímaného samotným žákem, druhá se týkala akademické marnosti, kterou žák vnímá u spolužáků, a třetí akademické marnosti, kterou žák vnímá u učitelů.

V roce 2008 se ke konceptu akademické marnosti vrátili vlámští výzkumníci Mieke Van Houtte a Peter J. A. Stevens, kteří jej aplikovali na zkoumání rozdílů mezi středními školami poskytujícími střední všeobecné a střední odborné vzdělávání ve vlámské části Belgie. Z původního trí́dimenzionálního 
konceptu použili pouze první dimenzi, tedy pocit akademické marnosti vnímané samotným žákem (Van Houtte \& Stevens, 2008). Ve svých výzkumech rozlišovali mezi pocitem akademické marnosti subjektivně vnímané jedincem a kulturou akademické marnosti, která je ovlivňována individuálními pocity jednotlivců, ale projevuje se na úrovni školy (Van Houtte \& Stevens, 2010). Ukázali, že v odborných školách ve vlámské části Belgie je akademická marnost pozorovatelná vyšší měrou než ve školách s akademickým programem a že tato kultura marnosti ovlivňuje studijní motivaci žáků a jejich zapojení do vzdělávacího procesu nezávisle na jejich subjektivním pocitu akademické marnosti. Kultura marnosti vysvětluje asociaci mezi typem školy a studijním úsilím a je zodpovědná za nižší studijní úsilí žáků v odborných školách. Agirdag et al. (2012) ukázali, že obě proměnné, tedy individuální pocit akademické marnosti a kultura akademické marnosti vysvětlují vztah mezi socioekonomickým složením žáků školy a jejich výsledky v matematice.

Na základě uvedených poznatků konstatovala Van Houtte (2016), že koncept akademické marnosti je velmi vhodný pro zachycení bariér, které brání žákům s nízkým socioekonomickým statusem se ve škole snažit, protože 1) má přímý vztah ke škole a ke vzdělávání, 2) explicitně se váže k představám o budoucím životě a o budoucím pracovním uplatnění a 3) zahrnuje vnímanou prýslušnost respondentů $\mathrm{k}$ nějaké skupině. Toto explicitní zacílení na vzdělání a skutečnost, že se jedinec cítí být součástí nějaké skupiny, činí z tohoto konceptu přesný a vhodný nástroj, který může zachytit situaci v nevýběrových tř́dách, respektive málo prestižních vzdělávacích programech.

Povaha konceptu akademické marnosti a jeho aplikace na studium rozdílů ve výsledcích žáků všeobecných a odborných škol v Belgii vedly autory tohoto textu $\mathrm{k}$ rozhodnutí adaptovat koncept do prostředí české střední školy. Nespokojili se však s jednodimenzionální variantou omezující se na pocit akademické marnosti vnímané samotným žákem, ale vrátili se k původnímu tř́́dimenzionálnímu konceptu Brookovera a Schneidera z roku 1975. Tři dimenze podle názoru autorủ lépe vystihují komplexní povahu konceptu akademické marnosti. Původní baterie Brookovera a Schneidera z roku 1975 byla adaptována pro prostředí současné české střední školy a validizována na souboru 4857 žáků z 29 gymnázií a 90 středních odborných škol, kteří ve školním roce 2018/2019 navštěvovali 3. ročník středoškolského studia. Baterie jevila dobré psychometrické vlastnosti v jednoúrovňové podobě (úroveň žáka - pocit akademické marnosti) i ve dvouúrovňové podobě (úroveň žáka - pocit akademické marnosti a úroveň tř́dy - kultura akademické marnosti). Z důvodu povahy konceptu a studovaných problémů autoři považují za vhodné pracovat s akademickou marností ve dvouúrovňové podobě, tedy rozlišovat mezi pocity individuálních žáků a tř́́dním kontextem (Straková et al., v tisku). 


\section{Výzkumné otázky, data, metody}

\section{Výzkumné otázky}

Cílem této studie je porozumět tomu, jaké faktory ovlivňují vzdělávací pokrok žáků v průběhu studia na střední škole v matematice a ve čtenářské gramotnosti. Záměrně volíme ty to dvě disciplíny, př́ičemž vycházíme z toho, že matematika je značně závislá na navštěvovaném oboru, oproti tomu čtenářská gramotnost je na jedné straně školou méně rozvíjena, na druhé straně by měla představovat základní výbavu absolventa jakéhokoli středoškolského oboru. $V$ analýze se zaměřujeme nejen na faktory, které škola může jen stěží ovlivnit, jako jsou vstupní vědomosti a rodinné zázemí žáků, ale také na faktory související s klimatem školy, které škola podle našeho názoru ovlivnit může, respektive se o to může snažit. Klima školy operacionalizujeme prostř̌ednictvím kultury akademické marnosti, zároveň pracujeme s pocitem akademické marnosti na úrovni žáka. Naše základní výzkumná otázka tedy zní: Ovlivňují pocit akademické marnosti na úrovni žáka a kultura akademické marnosti na úrovni tř́́dy výsledky žáků v matematice a ve čtenářské gramotnosti, zohledníme-li vstupní vědomosti a rodinné zázemí jednotlivých žáků, složení žákủ tř́ídy a navštěvovaný obor? Navazujeme zejména na práce Brookovera a Schneidera (1975) a Agirdaga et al. (2012).

Jednotkou agregace $\mathrm{v}$ naší analýze není škola, ale tř́da. Je tomu tak z toho důvodu, že v řadě stř̌edních škol se nyní nacházejí společně třídy odborných maturitních i nematuritních oborů, $v$ některých př́ípadech i třídy gymnaziální. Vycházíme z předpokladu, že pocit akademické marnosti se utváří na úrovni tř́dy, na základě studijní motivace žáků dané třídy i př́stupu učitelů k těmto žákům.

\section{Data}

Data využívaná v této studii byla získána $\mathrm{v}$ rámci longitudinálního výzkumu CLoSE (Czech Longitudinal Study of Education). V rámci tohoto výzkumu proběhlo na podzim 2016 šetření na výběru žáků v prvních ročnících středoškolského studia a na přelomu roku 2018/2019 šetření těch samých žáků $\mathrm{v}$ polovině 3. ročníku. $\mathrm{V}$ obou sběrech byli žáci testováni z matematiky, z českého jazyka a ze čtenářské gramotnosti. Zároveň vyplňovali dotazník mapující jejich rodinné zázemí, školní zkušenosti a postoje ke škole a vzdělávání. V roce 2018 byly součástí dotazníku rovněž otázky zaměřené na pocit akademické marnosti.

Šetření v obou vlnách se zúčastnilo 2846 žáků ze 143 tř́d (29 s programy odborného nematuritního vzdělávání, 58 s programy odborného maturitního vzdělávání a 56 tř́íd gymnaziálních) v 79 školách (50 odborných škol 
a 29 gymnáziî $)^{5}$. Gymnazisté byli ve výzkumu nadreprezentováni, z toho důvodu byla data převážena podle zastoupení v jednotlivých programech, tedy v gymnaziálním studiu, ve středním odborném studiu s maturitou a středním odborném studiu bez maturity. ${ }^{6} \mathrm{~V}$ analýze jsme nerozlišovali mezi žáky čtyřletých a víceletých gymnaziálních programů, žáci víceletých gymnázií byli nicméně ve výběru zastoupeni tak, jak odpovídá jejich podílu na populaci gymnazistů.

\section{Metody}

Analýzy jsou založeny na dvouúrovňovém strukturním modelování v programu MPlus. Na první úrovni modelujeme vztahy na úrovni žáka, na druhé úrovni vztahy na úrovni tř́dy. Vysvětlované proměnné jsou výsledek v matematickém testu v polovině třetího ročníku studia (mat3) a výsledek ve čtenářském testu $\mathrm{v}$ polovině třetího ročníku studia (cg3). Pro volbu dvouúrovňového modelu byla $\mathrm{v}$ tomto př́padě řada dobrých důvodů: 1) dvoustupňový výběr, kdy nejdříve byly vybírány školy a následně pak žáci v těchto školách, 2) jde nám o to zachytit proměnné, které působí na individuální úrovni, i proměnné, které působí na úrovni třídy, 3) mezi školami existují ve sledovaných proměnných velké rozdíly: $\mathrm{v}$ testu $\mathrm{v}$ matematice ve 3. ročníku je možno rozdíly mezi školami vysvětlit $64 \%$ rozdílů ve výsledcích žáků, v testu čtenářské gramotnosti 53 \% rozdílů.

Testy z matematiky a ze čtenářské gramotnosti pro 1. a 3. ročník byly koncipovány obdobně s tím, že obtížnost úloh byla volena tak, aby test jako celek byl schopen zachytit vývoj ve vědomostech a dovednostech mezi 1. a 3. ročníkem. Testy byly vždy vyvinuty ve dvou paralelních variantách A a B, aby bylo eliminováno opisování. Testy z matematiky i ze čtenářské gramotnosti obsahovaly zhruba 30 úloh, $z$ toho polovinu otevřených vyžadujících vlastní odpověd' ( $\mathrm{v}$ matematice převážně číselnou, ve čtenářské gramotnosti stručnou či rozšířenou slovní odpověd') a polovinu uzavřených otázek s výběrem odpovědi.

Matematické úlohy pokrývaly tři obsahové okruhy učiva: číslo a početní operace, závislosti, vztahy a práce s daty a geometrie v rovině a prostoru, resp. dvojrozměrné a trojrozměrné útvary. Většina úloh byla inspirována úlohami z výzkumu TIMSS nebo z testů společné části maturitní zkoušky

Analýza byla provedena na tomto datovém souboru, pro víceúrovňové modelování bylo nicméně nutno eliminovat všechny chybějící hodnoty, víceúrovňové modelování tedy bylo realizováno na souboru 2641 respondentů.

6 Váhy vycházely z údajů o počtech žáků v 1. ročnících jednotlivých programů vyššího sekundárního studia uvedených ve statistické ročence školství z roku 2016/2017. 
CZVV. Některé byly přímo převzaty, pro některé byly vytvořeny párově ekvivalentní varianty. Několik úloh bylo nově autorsky vytvořeno pro účely projektu CLoSE.

V testu čtenářské gramotnosti byly použity uvolněné úlohy z mezinárodních šetření čtenářské gramotnosti PISA a autorské úlohy. Každý sešit obsahoval šest výchozích textů a $\mathrm{k}$ nim se vztahovalo 3-6 úloh. Úlohy byly zaměřeny na tři oblasti čtenářských dovedností: vyhledávání informací (obsažených $\mathrm{v}$ textu), zpracování informací (hledání vnitřních souvislostí a vztahů obsažených $\mathrm{v}$ textu) a zhodnocení textu (propojování s informacemi, které nejsou $\mathrm{v}$ textu obsaženy).

Správnost uzavřených odpovědí byla vyhodnocována $\mathrm{v}$ př́padě obou testů automaticky, otevřené úlohy byly vyhodnocovány dvěma nezávislými hodnotiteli. Výsledek v testu (procentuální úspěšnost) byl vypočten jako podíl správně vyřešených úloh ku všem úlohám v testu.

Akademická marnost byla měřena celkem 13 otázkami, přičemž 4 otázky zjišstovaly akademickou marnost vnímanou žáky od učitelů (Cronbachovo $\alpha=0,716), 3$ otázky zjišstovaly akademickou marnost vnímanou od spolužáků (Cronbachovo $\alpha=0,713)$ a 6 otázek pocit akademické marnosti samotného žáka (Cronbachovo $\alpha=0,911)$. Na základě konfirmační analýzy byly z baterie vyloučeny položky s opačnou polaritou (viz Straková, Soukup, \& Simonová, v tisku). Formulace otázek, které byly použity v této studii pro výpočet akademické marnosti, je uvedena $v$ př́loze 1 včetně deskriptivních statistik. Použitý konstrukt vykazoval reliabilitu $\alpha=0,795$.

Nezávislé proměnné, které vstupují do analýz na individuální žákovské úrovni:

- procentuální úspěšnost v matematickém testu na začátku středoškolského studia (mat1)

- procentuální úspěšnost ve čtenářském testu na začátku středoškolského studia (cg1)

- socioekonomický status (ses) - faktorový skór vzdělání matky a vzdělání otce na čtyřstupňové škále: 1 - základní, 2 - střední bez maturity, 3 - střední s maturitou, 4 - vysokoškolské; povolání matky a povolání otce (první číslice kódu klasifikace ISCO překódována tak, že vedoucí pozice mají kód 9 a nekvalifikované práce kód 1) a počet knih v domácnosti (6 kategorií: první: 0-10, šestá: více než 500). Vyšší hodnota indikuje vyšší socioekonomický status

- akademická marnost (am) - skór byly vygenerován z konfirmační faktorové analýzy, ve které byl index akademické marnosti konstruován ze tří komponent: pocit akademické marnosti samotného žáka (sycena 5 položkami), vnímaná akademická marnost spolužáků (sycena 3 položkami), vnímaná akademická marnost učitelů (sycena 2 položkami). Vyšší hodnota indikuje silnější pocit akademické marnosti 
Nezávislé proměnné, které vstupují do analýz na úrovni třídy:

- výsledek $\mathrm{v}$ matematickém testu na začátku středoškolského studia agregovaný na úroveň tř́́dy - průměrný výsledek tř́ídy v matematice (MAT1)

- výsledek ve čtenářském testu na začátku středoškolského studia agregovaný na úroveň třídy - průměrný výsledek třídy ve čtenářské gramotnosti (CG1)

- socioekonomický status agregovaný na úroveň tř́dy (SES)

- kultura akademické marnosti (AM)

- gymnaziální program $(\mathrm{G})$, gymnázium $\mathrm{G}=1$, odborné obory $\mathrm{G}=0$

Deskriptivní statistiky proměnných použitých v modelech jsou uvedeny v príloze 2.

Kvalita modelů byla posuzována podle ukazatelů $\mathrm{RMSEA}^{7}, \mathrm{TLI}^{8}, \mathrm{CFI}^{9}$ a SRMR ${ }^{10}$. Vybrali jsme kritéria, která jsou v oblasti strukturního modelování nejběžnější, také popsané doporučené meze respektují většinovou praxi v této oblasti. Samozřejmě jsme si vědomi, že ani splnění těchto doporučení negarantuje automaticky kvalitu modelu. Pro úplnost uvádíme u jednotlivých modelů rovněž hodnotu Chi - kvadrát testu ${ }^{11}$.

7 Root mean square error of approximation udává, jak dobře model odpovídá populační kovarianční matici. Hu a Bentler (1998) považují pro vyhovující modely za maximální hodnotu RMSEA 0,06.

$8 \quad$ Tucker-Lewis index hodnotí model na základě porovnání hodnoty $\chi^{2}$ našeho modelu a $\chi^{2}$ nulového modelu (modelu nezávislosti).

9 Comparative Fit index je analogický indexu TLI (tj. srovnává konkrétní model a model nezávislosti) s tím, že bere v úvahu též velikost výběru. Hu a Bentler (1998) považují za doklad dobré shody s daty v př́padě ukazatelů TLI a CFI hodnoty vyšší než 0,9 .

10 Standardized root mean square residual je druhá odmocnina z rozdílu mezi rezidui kovarianční matice a hypotetického kovariančního modelu. Za indikaci dobrého modelu je považována hodnota 0,05 a nižší (nap̌r. Byrne, 1998).

11 Test srovnává kovarianční matici ze získaných dat a kovarianční matici, která vznikne při užití modelu. Tento test je citlivý jednak na velikost souboru (pro větší datové soubory typicky vede k zamítání hypotézy o shodě kovariačních matic) a komplikovanost modelu (pro složitější modely vede zpravidla k zamítání hypotézy o shodě kovariačních matic). Výsledky testu uvádíme zejména pro úplnost posouzení, některá z výše uvedených kritérií (CFI, TLI) vycházejí z hodnoty tohoto testového kritéria a odstraňují jeho citlivost na velikost datového souboru, resp. komplexnost modelu. 


\section{Výsledky}

\section{Faktory ovlivnúujicí ćtenárskou gramotnost}

Obrázky 1 a 2 ukazují dvouúrovňové modely faktorů ovlivňujících výsledky ve čtenářské gramotnosti ve 3. ročníku středoškolského studia. První, základní model zahrnuje pouze počáteční vědomosti a socioekonomický status na individuální úrovni a na úrovni tř́ídy socioekonomické složení žáků, vědomostní úroveň třídy a typ studia. Do druhého modelu vstupuje na individuální úrovni pocit akademické marnosti a na úrovni tř́dy kultura akademické marnosti. Oba modely vykazují dobrou shodu s daty, základní model má RMSEA $=0,049$, CFI $=0,998$, TLI $=0,968$, SRMR na první úrovni $=$ 0,00, SRMR na druhé úrovni $=0,010$, Chi-kvadrát test $=7,438$ při 1 stupni volnosti. Tento model vysvětluje $33 \%$ rozptylu na úrovni žáka a $66 \%$ rozptylu na úrovni tř́dy.

Model zahrnující akademickou marnost má RMSEA $=0,034$, CFI $=0,995$, TLI $=0,972$, SRMR na první úrovni $=0,029$, SRMR na druhé úrovni $=$ 0,040 , Chi-kvadrát test $=12,470$ při třech stupních volnosti. Tento model vysvětluje $34 \%$ rozptylu na úrovni žáka a $69 \%$ rozptylu na úrovni tř́́dy. Koeficienty v obou modelech jsou standardizovány, tedy je možno je přímo porovnávat.

Z prvního modelu vyplývá, že na individuální úrovni je výsledek ve 3. ročníku silně ovlivněn výsledkem v 1. ročníku. Oba výsledky jsou ovlivněny socioekonomickým statusem žáka. $\mathrm{Na}$ úrovni tř́ídy je výsledek ovlivněn socioekonomickým složením žáků a příznivě se projevuje i gymnaziální zaměření, které má rovněž vazbu na socioekonomické složením žákủ. Při zohlednění socioekonomického složení tř́dy se již neuplatňuje složení studijní - celkový výsledek trŕ́dy v testu v 1. ročníku k výsledku ve 3. ročníku nepřispívá.

Přidáme-li do modelu pocit akademické marnosti, na žákovské úrovni se uplatňuje nad rámec socioekonomického statusu. Zatímco socioekonomický status má pozitivní vazbu s výsledky v obou testech, pocit akademické marnosti má vazbu negativní, to znamená, že žáci se silnějším pocitem akademické marnosti dosahují horších výsledků. Zahrnutí kultury akademické marnosti, tedy jakéhosi pocitu akademické marnosti sdíleného celou tř́idou, na úroveň třídy, způsobí, že gymnaziální zaměření přestává mít přímý dopad na výsledek v testu. Gymnaziální zaměření má (negativní) vazbu ke kultuře akademické marnosti, to znamená, že kultura akademické marnosti je vyšší v odborných školách. Akademická marnost pak ovlivňuje testové výsledky v obou ročnících, tedy podílí se na horších výsledcích žáků odborných škol. 
Úroveň žáka

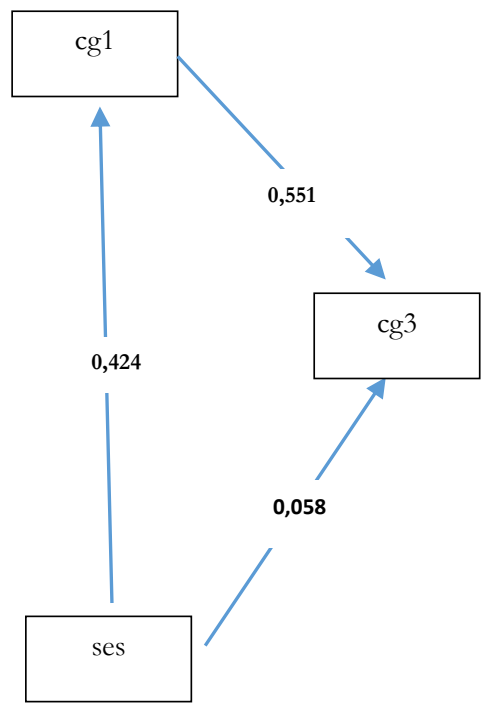

Úroveň třídy

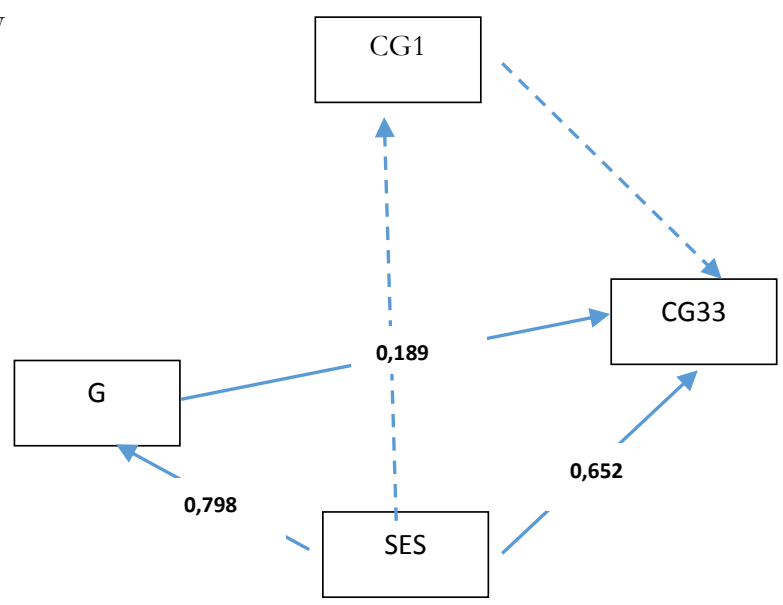

Obrázek 1

Dvounrovnový strukturní model faktorù ovlivnuujicich úroven čtenárské gramotnosti ve 3. ročniku SŠ (základni model, standardizované regresni koeficienty ${ }^{12}$; vątahy, které se neprokázaly jako statisticky významné, jsou vyznačeny cárkovanè).

12 Jde o známé beta-koeficienty z regresní analýzy, které skrze standardizaci odstraňujî měřicí stupnice výchozích proměnných a umožňují prýímo srovnat vliv jednotlivých prediktorů. 
Úroveň žáka

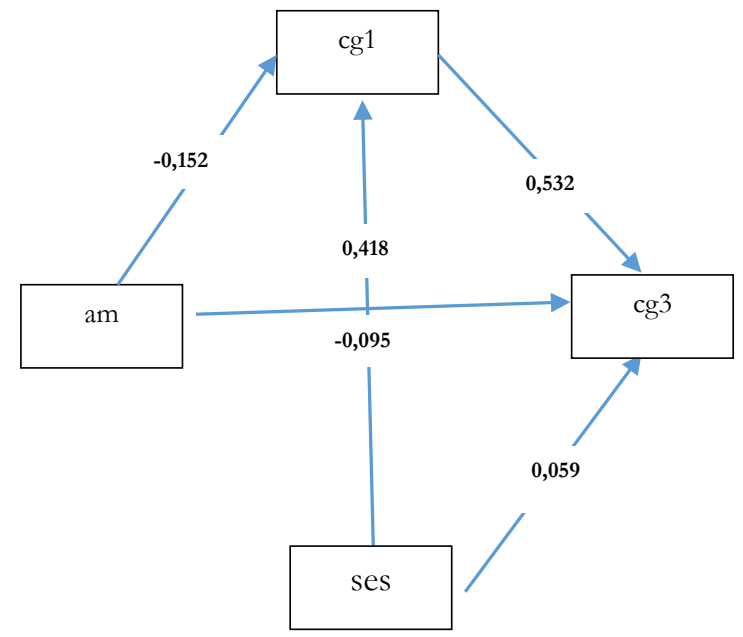

Úroveň třídy

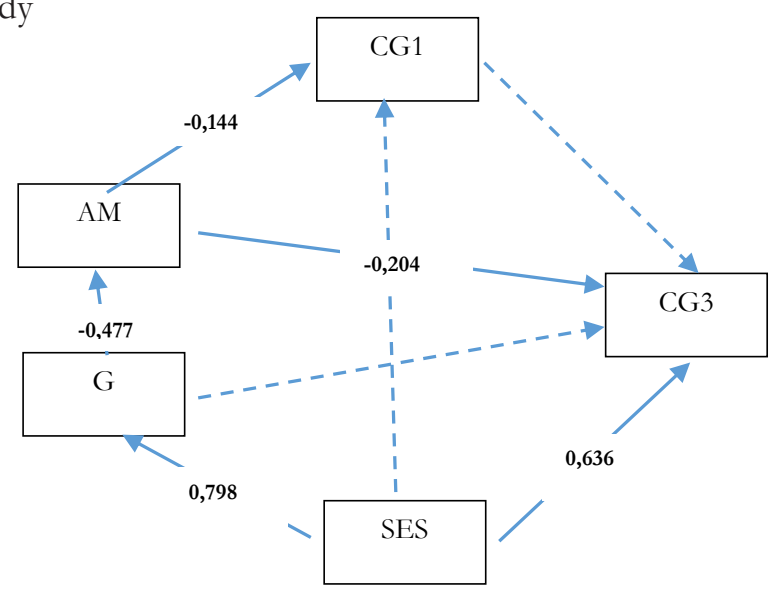

Obrázek 2

Dvouírovñový strukturni model faktorù ovlivnuuicich úroveñ čtenárské gramotnosti ve 3. ročníku SŠ (vliv akademické marnosti, standardizované regresní koeficienty; vz̨taby, keteré se neprokázaly jako statisticky výżamné, jsou vyznačeny čárkovaně). 


\section{Faktory ovlivnuujici védomosti a dovednosti v matematice}

Obrázky 3 a 4 ukazují analogické modely pro výsledky v matematickém testu. Tyto modely rovněž vykazují dobrou shodu s daty. Základní model má RMSEA $=0,067$, CFI $=0,995$, TLI $=0,958$, SRMR na první úrovni $=0,000$, SRMR na druhé úrovni $=0,034$, Chi-kvadrát test $=12,993$ při 1 stupni volnosti. Tento model vysvětluje $51 \%$ rozptylu na úrovni žáka a $63 \%$ rozptylu na úrovni tř́dy.

Model zahrnující akademickou marnost má RMSEA $=0,028, \mathrm{CFI}=0,998$, TLI $=0,988$, SRMR na první úrovni $=0,012$, SRMR na druhé úrovni $=$ 0,025 , Chi-kvadrát test 8,158 při 3 stupních volnosti. Tento model vysvětluje $50 \%$ rozptylu na úrovni žáka a $64 \%$ rozptylu na úrovni tř́dy.

Model vykazuje ve srovnání s modelem týkajícím se čtenářské gramotnosti určité odlišnosti. V základním modelu je obrázek na úrovni žáka podobný, na úrovni tř́dy jsou však výsledky ve 3. ročníku ovlivněny dominantně souhrnnými výsledky v prvním ročníku, tedy studijní úrovní třídy. Faktor gymnaziálního zaměření je na hranici statistické významnosti. Zdá se tedy, že na úrovni tř́dy jsou výsledky ovlivněny pouze tím, co žák umí již na vstupu do středního vzdělávání.

Druhý model ukazuje, že individuální pocit akademické marnosti nemá na výsledky vliv. Kultura akademické marnosti na úrovni tř́dy se neuplatňuje přímo, ale pouze prostřednictvím studijní úrovně třídy aproximované celkovým výsledkem $\mathrm{v}$ testu na počátku studia. Faktor gymnaziálního zaměření zůstává i po zahrnutí kultury akademické marnosti na hranici statistické významnosti. Výsledky druhého modelu tedy podporují interpretaci, že v průběhu středního vzdělávání žák musí stavět především na výsledcích, se kterými do školy přišel. Střední odborné školy mají horší socioekonomické složení žáků a vyšší kulturu akademické marnosti. Mají horší průměrný výsledek na počátku studia, který zapříčiňuje i horší výsledek ve 3. ročníku. 
Úroveň žáka

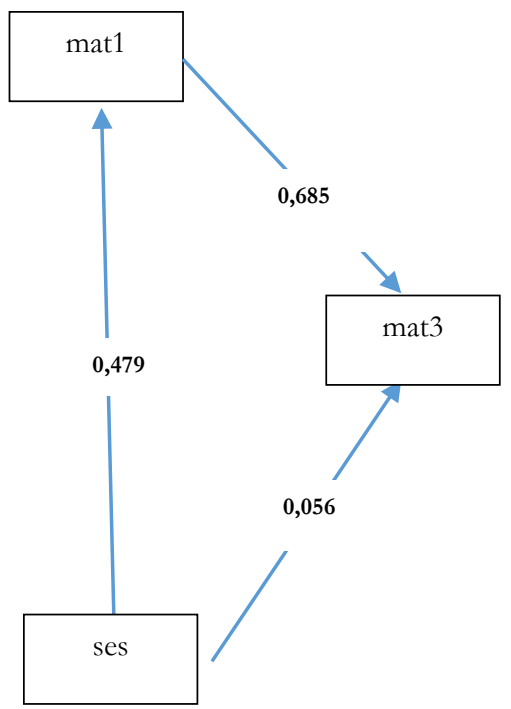

Úroveň tř́idy
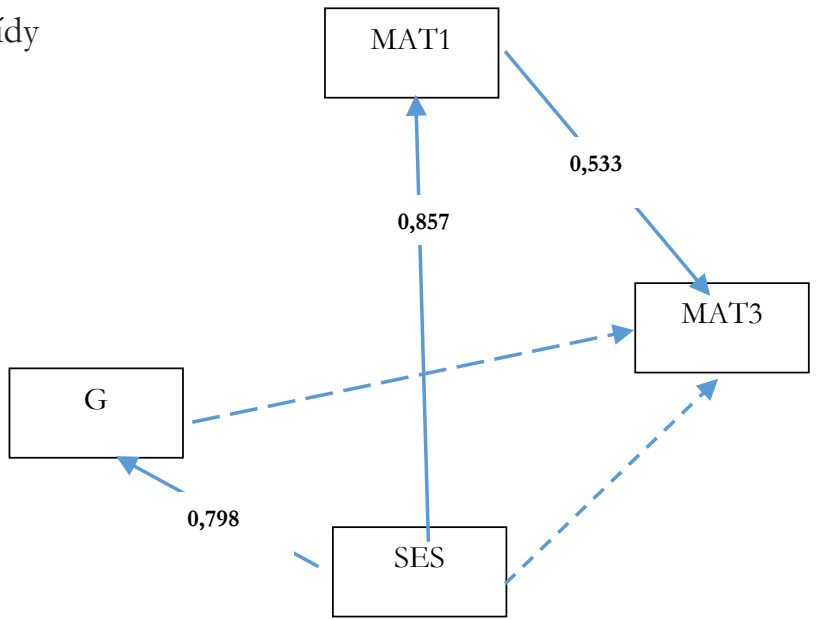

Obrázek 3

Dvouúrovňový strukturni model faktori ovlivñujicich úroveñ matematických védomostí ve 3. ročníku SS̆ (základni model, standardizované koeficienty; vztaby, které se neprokázaly jako statisticky významné, jsou vyznačeny čárkované). 
Úroveň žáka

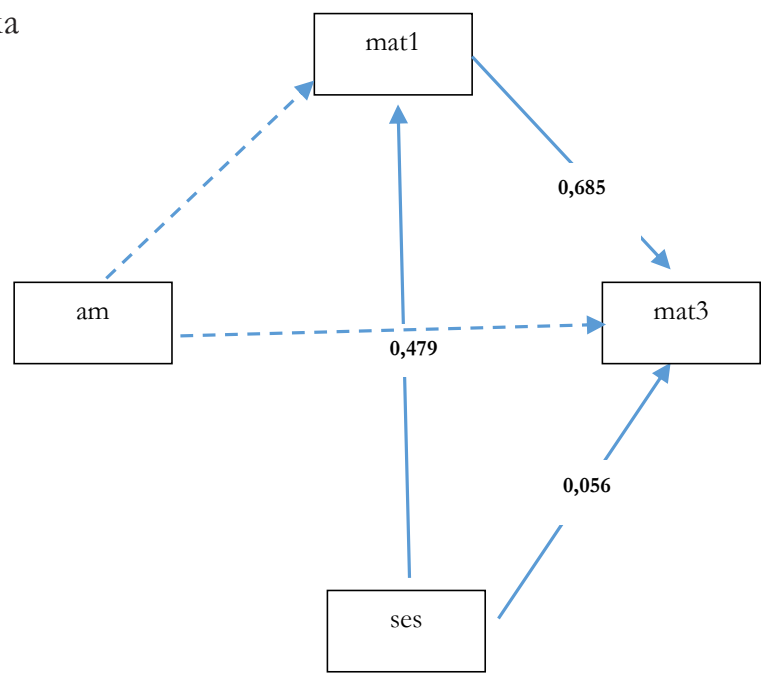

Úroveň třídy

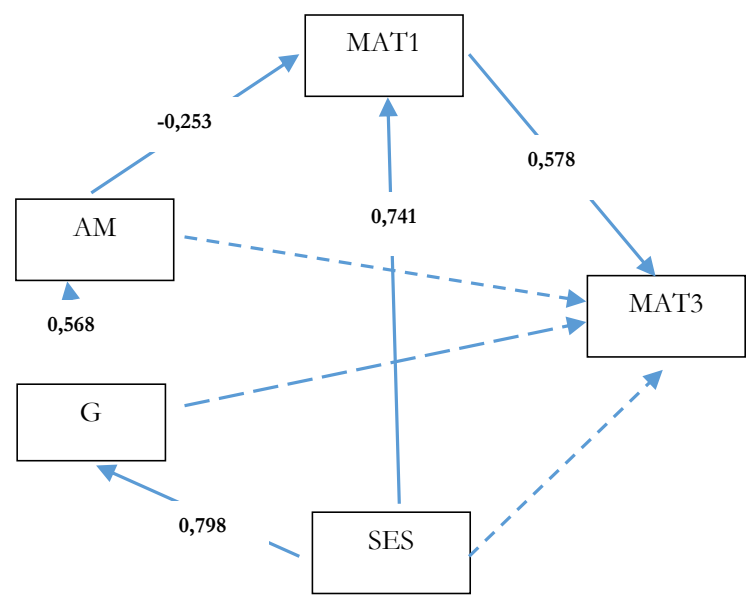

Obrázek 4

Dvouńrovňový strukturní model faktorü ovlivnujujicich úroveñ matematickéch védomostí ve 3. ročníku SS̆ (vliv akademické marnosti, standardizované koeficienty; vžtaby, které se neprokázaly jako statisticky významné, jsou vyznačeny čárkované). 


\section{Diskuse}

Analýzy představené $\mathrm{v}$ této stati potvrzují užitečnost konceptu akademické marnosti pro vysvětlení výsledků vzdělávání v závěru středoškolského studia. V př́padě čtenářské gramotnosti akademická marnost přímo ovlivňuje výsledky, a to jak na úrovni jednotlivých žáků jako pocit akademické marnosti, tak na úrovni třídy prostřednictvím sdílené kultury akademické marnosti. Ve vztahu ke čtenářské gramotnosti kultura akademické marnosti odstiňuje přímý vliv gymnaziálního zaměření na výsledky. Gymnaziální studium však snižuje kulturu akademické marnosti, tedy ovlivňuje výsledek jejím prostřednictvím nepřímo. Žáci středních odborných škol se naopak vzdělávají v prostředí, které vykazuje vyšší kulturu akademické marnosti, a jejich výsledky jsou touto kulturou negativně ovlivňovány. Z modelů čtenářské gramotnosti můžeme v každém případě usuzovat na to, že úsilí školy o snížení pocitu akademické marnosti u jednotlivých žáků a kultury akademické marnosti $\mathrm{v}$ jednotlivých tř́dách by se mělo pozitivně odrazit ve výsledcích žáků.

$\mathrm{V}$ př́padě matematických vědomostí se individuální pocit akademické marnosti neuplatňuje a kultura akademické marnosti se uplatňuje pouze neprrímo, prostřednictvím studijní úrovně třídy aproximované průměrným výsledkem $\mathrm{v}$ matematickém testu na počátku studia. I v tomto př́padě však kultura akademické marnosti může být považována za důležitý mediátor mezi socioekonomickým složením tř́ídy a vzdělávacími výsledky. V tomto smyslu naše výsledky potvrzují výsledky zahraničních studií zaměřených na zkoumání vztahu školního klimatu $\mathrm{k}$ výsledkům vzdělávání (např. Berkowitz et al., 2016; Uline \& Tschannen-Moran, 2008). Zároveň opět potvrzují horší situaci středních odborných škol.

Rozdíly mezi matematikou a čtenářskou gramotností přičítáme tomu, že matematický test ve 3. ročníku byl pro řadu žáků obtížný. Zdá se, že rozhodující při jeho zvládnutí byly matematické vědomosti a dovednosti, které se projevily již při testování v prvním ročníku. Ty ovšem byly na úrovni třídy ovlivněny kulturou akademické marnosti a socioekonomickým složením žáků, přičemž gymnaziální obory mají prúínivější složení žáků a nižšíi kulturu akademické marnosti. Zároveň je zajímavé, že z hlediska matematických vědomostí a dovedností ve 3. ročníku nepředstavuje gymnaziální studium přímou dělicí čáru. To se projevuje opět pouze vazbou na výsledek v prvním ročníku. Otázka pro další výzkum je, zda je tento jev skutečně charakteristický pro matematické vzdělávání na úrovni střední školy, nebo zda je vedlejším produktem prŕliš obtížného matematického testu.

Oproti tomu ve čtenářské gramotnosti jsme zaznamenali vliv gymnaziálního studia prostřednictvím kultury akademické marnosti, která má přímý vliv na výsledky v testu čtenářské gramotnosti ve 3. ročníku. Přímý vliv zde 
má rovněž socioekonomické složení třídy. Naopak souhrnný výsledek žáků $\mathrm{v}$ prvním ročníku se $\mathrm{v}$ př́padě čtenářské gramotnosti neuplatňuje. Zdá se tedy, že zde je výsledek více ovlivněn tím, co se děje ve škole a jaká ve tř́idě panuje atmosféra. Ta je ovšem příznivějš́i v gymnaziálních programech.

Naše studie potvrdila, že v odborném vzdělávání se žáci setkávají s kulturou akademické marnosti ve větší míře než v gymnaziálním vzdělávání. Tento nález odpovídá poznatkům Van Houtte a Stevense (2010, 2015), které ukázaly, že kultura akademické marnosti vysvětluje vztah mezi motivací ke studiu a studijní aktivitou a je odpovědná za méně studijně orientované prostředí na odborných školách.

Výsledky také ukazují, že akademická marnost se uplatňuje vedle ukazatele socioekonomického statusu, což odpovídá výsledkům Agirdag et al. (2012). Ti ukázali ve výzkumu na vlámských středních školách, že pocity studentů a klima trŕdy nelze připsat pouze socioekonomickému statusu žáků. To je samo o sobě důležité, protože Brookover a Schneider (1975) navrhli koncept akademické marnosti právě s cílem identifikovat faktory, které by mohly vysvětlit rozdíly v úrovních výsledků mezi školami nad rámec socioekonomického složení studentů. Reagovali tak na výzkumy (nap̌r. Coleman et al., 1966; Hauser, 1971), které ukazovaly silný vliv rodinného zázemí na výsledky žáků a naznačovaly, že škola má na výsledky vzdělávání jen malý vliv. Brookover a Schneider (1975) se domnívali, že tyto poznatky mohou být artefaktem toho, jak školu charakterizujeme. Domnívali se, že když nalezneme vhodné charakteristiky škol, můžeme ukázat, že dopad škol a učitelů na výsledky žáků je významný. I v České republice často ztotožňujeme výsledky v jednotlivých programech se složením žáků, kteří tyto programy navštěvují, a nevěnujeme se dostatečně faktorům působícím na úrovni školy. Studie zaměřené na sledování různých dimenzí školního klimatu přitom ukazují, že se jejich vliv uplatňuje nad rámec daný socioekonomickým zázemím žáků školy. Např́klad přehledová studie (Wang \& Degol, 2016) ukázala, že žáci ve školách s vysokými akademickými standardy, efektivním leadershipem, zdůrazňující důležitost zvládnutí cílů učení a vyučování, dobrými vztahy mezi žáky a učiteli a častou komunikací mezi školou a rodiči dosahují lepších výsledků.

Koncept akademické marnosti považujeme za velmi užitečný proto, že umožňuje nový pohled na mechanismy, které způsobují rozdíly ve výsledcích vzdělávání nejen mezi programy středních škol, ale obecně mezi školami a tř́dami navštěvovanými žáky s různým rodinným zázemím. Kromě toho, že nám pomáhá lépe porozumět tomu, jak se formují postoje žáků a jak ovlivňují jejich kognitivní výsledky, umožňuje také zaměřit pozornost na aspekty školního života, které by mohly být ovlivněny samotnou školou nebo vzdělávací politikou. I když nemůžeme legitimním zpo̊sobem ovlivnit socio- 
ekonomické složení žáků škol, můžeme se pokusit zdůraznit důležitost postojů učitelů $\mathrm{k}$ žákům a způsob, jakým komunikují svá očekávání. Důležitost těchto postojů a očekávání je podle našeho názoru v českém vzdělávacím systému nedoceňována. Více než nyní by měla být diskutována s budoucími učiteli v rámci jejich př́pravného vzdělávání i s praktikujícími učiteli v kurzech dalšího vzdělávání.

Výsledky naší studie ukazují, že má smysl věnovat úsilí tomu, aby žáci nezískávali ve škole neoprávněně pocit, že nemá cenu se snažit, protože není $\mathrm{v}$ jejich moci ovlivnit výsledky, které dosahují. Péči je potřeba věnovat způsobu poskytování zpětné vazby směrem od učitelů i vztahům mezi žáky ve tř́̃dách - skupinová dynamika může ve významné míře ovlivňovat vnímání studijního úsilí vrstevníky.

Zvláštní pozornost je vhodné věnovat studentům odborných škol. Mnozí z nich přicházejí do stř̌edního vzdělání vybaveni nedostatečnými znalostmi a dovednostmi v oblasti matematiky a čtenářské gramotnosti již ze základního vzdělávání a chybí jim základy, na kterých by mohli stavět své další vzdělávání. $V$ tomto směru by mohla být př́nosná pozitivní zpětná vazba i při zdánlivě malých pokrocích, která může ovlivnit vnímání školní úspěšnosti zvláště pro žáky z méně podnětného socioekonomického zázemí.

Vzhledem k potvrzení vztahu mezi výsledky a pocitem akademické marnosti je do budoucna potřeba věnovat výzkumnou pozornost také faktorům, které pocit akademické marnosti utvářejí, a to již na úrovni základního vzdělávání. Kultura akademické marnosti se začíná vytvářet již na prvním stupni, proto je také potřeba odhalit faktory, které ji ovlivňují, aby bylo možné začít s intervencí co nejdříve.

Studie také zdůraznila potřebu věnovat pozornost vedlejším účinkům rozdělení žáků do programů, které má za následek odlišné klima v jednotlivých programech. Odborné školy jsou zranitelnější vůči vzniku tř́́dního klimatu zatíženého kulturou akademické marnosti, což má negativní dopad na výsledky žákủ. Školy a učitelé by se měli snažit vědomě potlačovat pocity akademické marnosti u svých žáků. Z toho důvodu se tvůrci vzdělávacích politik vyspělých zemí zaměřují na to, jak koncipovat odborné vzdělávání tak, aby bylo pro žáky co nejužitečnější i z hlediska dlouhodobější, nikoli pouze krátkodobé perspektivy, a snaží se učinit odborné programy zajímavé pro žáky všech sociálních vrstev. Předpokládají, že větší heterogenita žákovských kolektivů a vnímaná užitečnost pomohou utváření negativní atmosféry, ke které kultura akademické marnosti bezpochyby patří, eliminovat. 


\section{Limity studie}

Zřejmou slabinou této studie je skutečnost, že akademická marnost byla měřena pouze ve třetím ročníku středoškolského studia. Naše výpočty jsou tedy založeny na předpokladu, že se akademická marnost $\mathrm{v}$ průběhu studia nemění a je ve všech programech konstantní. Tento předpoklad nemusí být správný. Aby bylo možné plně porozumět faktorům ovlivňujícím výsledky vzdělávání $\mathrm{v}$ jednotlivých programech, bude $\mathrm{v}$ budoucnu nutné důkladně se poučit o tom, kde se pocit akademické marnosti primárně utvář́ a jak se vyvijí během středoškolského studia.

\section{Závěr}

Pomocí dvouúrovňového strukturního modelování jsme ukázali, že na české střední škole ovlivňuje akademická marnost vzdělávací výsledky na úrovni jednotlivce $\mathrm{i}$ tř́́dy, i když vezmeme v úvahu socioekonomický status, počáteční výsledky, složení žáků třídy a navštěvovaný vzdělávací program, přičemž se uplatňuje $\mathrm{v}$ matematice a ve čtenářské gramotnosti poněkud odlišným způsobem. Potvrdili jsme poznatky zahraničních výzkumů, které ukázaly, že žáci v odborném vzdělávání se ve svých školách vyšší měrou setkávají s kulturou akademické marnosti. Výsledky umožňuji upozornit tvůrce vzdělávací politiky a učitele a ředitele odborných škol na důležité aspekty školního kontextu.

\section{Literatura}

Agirdag, O., Van Houtte, M., \& Avermaet, P. (2012). Why does the ethnic and socio-economic composition of schools influence math achievement? The role of sense of futility and futility culture. European Sociological Review, 28(3), 366-378. https://doi.org/10.1093/ esr/jcq070

Alpert, B., \& Bechar, S. (2008). School organisational efforts in search for alternatives to ability grouping. Teaching and Teacher Education, 24(6), 1599-1612. https://doi.org/10.1016/j. tate.2008.02.023

Berkowitz, R., Moore, H., Astor, R. A., \& Benbenishty, R. (2016). A research synthesis of the associations between socioeconomic background, inequality, school climate, and academic achievement. Review of Educational Research, 87(2), 425-469. https://doi. org/10.3102/0034654316669821

Blažek, R., Janotová, Z., Potužníková, E., \& Basl, J. (2019). Męinárodni šetreni PIS A 2018. Národni zpráva. ČŠI.

Brookover, W. B., \& Schneider, J. M. (1975). Academic environments and elementary school achievement. Journal of Research and Development in Education, 9(1), 82-91.

Byrne, B. M. (1998). Structural equation modelling with lisrel, prelis and simplis: basic concepts, applications and programming. Lawrence Erlbaum Associates. https://doi.org/10.4324/9780203774762 
Coleman, J., Campbell, E., Hobson, C., Mcpartland, J., Mood, A., Weinfeld, F., \& York, R. (1966). Equality of educational opportunity. US Government Printing Office.

Dockx, J., \& De Fraine, B. (2018). On track for unemployment? Long-term effects of tracks. School Effectiveness and School Improvement, 30(2), 131-154. https://doi.org/10.1080/0924345 3.2018.1537292

Dzúrová, D., Csémy, L., Spilková, J., \& Lustigová, M. (2015). Zdravotnè rižikové chování mládeže $v$ Ceskeu. Státní zdravotní ústav.

Eichhorst, W., Rodríguez-Planas, N., Schmidl, R., \& Zimmermann, K. F. (2015). A road map to vocational education and training in industrialized countries. ILR Review, 68(2), 314-337. https://doi.org/10.1177/0019793914564963

Grecmanová, H. (2008). Klima školy. Hanex.

Grecmanová, H., Dopita, M., Poláchová Vašt’atková, J., \& Skopalová, J. (2012). Klima školy. Soubor dotaznik ů pro učitele, žáky a rodiče. Národní ústav pro vzdělávání.

Hampf, F., \& Wößmann, L. (2016). Vocational vs. general education and employment over the life-cycle: new evidence from PIAAC.CESifo Economic Studies, 63(3), 255-269. https:// doi.org/10.1093/cesifo/ifx012

Hanushek, E. A., \& Wößmann, L. (2006). Does educational tracking affect performance and inequality? Differences-in-differences evidence across countries. The Economic Journal, 116(510), C63-C76. https://doi.org/10.1111/j.1468-0297.2006.01076.x

Hanushek, E. A., Wößmann, L., \& Zhang, L. (2011). General education, vocational education, and labor-market outcomes over the life-cycle. National Bureau of Economic Research.

Hauser, R. M. (1971). Socio-economic background and educational performance. American Sociological Association.

Hlad’o, P. (2010). Vliv sociálního okolí na kariérové rozhodování žáků při přechodu do vyššího sekundárního vzdělávání. Pedagogická orientace, 20(3), 66-81. https://journals.muni. cz/pedor/article/view/1379

Hlad'o, P., \& Balcar, J. (2012). Sociálně-psychologické aspekty volby technického a humanitního studijního zaměření při tranzici žáků do maturitních oborů na středních školách. Pedagogická orientace, 22(4), 544-564. http://dx.doi.org/10.5817/PedOr2012-4-544

Hlad'o, P., \& Ježek, S. (2018). Measurement of career-specific parental behaviors perceived by Czech adolescents. Studia paedagogica, 23(2), 101-135. https://doi.org/10.5817/SP2018-2-7

Hlad’o, P., \& Šlapalová, K. (2019). „Už to dál nešlo“ - meziškolní mobilita ve stř̌edním odborném vzdělávání zpětným pohledem žáků. Pedagogika, 69(2), 147-164. https://doi. org/10.14712/23362189.2018.852

Hu, L.-T., \& Bentler, P. M. (1998). Cutoff criteria for fit indexes in covariance structure analysis: conventional criteria versus new alternatives. Structural Equation Modeling: A Multidisciplinary Journal, 6(1), 1-55. https://doi.org/10.1080/10705519909540118

Kelly, S., \& Carbonaro, W. (2012). Curriculum tracking and teacher expectations: evidence from discrepant course taking models. Social Psychology of Education, 15(3), 271-294. https:// doi.org/10.1007/s11218-012-9182-6

Kunter, M., \& Baumert, J. (2006). Who is the expert? Construct and criteria validity of student and teacher ratings of instruction. Learning Environments Research, 9(3), 231-251. https:// doi.org/10.1007/s10984-006-9015-7

Maaz, K., Trautwein, U., Lüdtke, O., \& Baumert, J. (2008). Educational transitions and differential learning environments: how explicit between-school tracking contributes to social inequality in educational outcomes. Child Development Perspectives, 2(2), 99-106. https:// doi.org/10.1111/j.1750-8606.2008.00048.x 
Oakes, J. (2005). Keeping Track: How Schools Structure Inequality. Yale University Press.

OECD. (2019). Education at a Glance. OECD.

Page, R. N. (1991). Lower-track classrooms: a curricular and cultural perspective. Teachers College Press.

Rubin, B., \& Noguera, P. (2004). Tracking detracking: sorting through the dilemmas and possibilities of detracking in practice. Equity and Excellence in Education, 37(1), 92-101. https://doi.org/10.1080/10665680490422142

Straková, J. (2015). Strong vocational education - a safe way to the labour market? A case study of the Czech Republic. Educational Research, 57(2), 168-181. https://doi.org/10.1080 /00131881.2015.1030853

Straková, J., \& Simonová, J. (2013). Vliv navštěvované střední školy na občanské postoje středoškoláků v ČR. Orbis scholae, 7(3), 27-47. https://doi.org/10.14712/23363177.2015.12

Straková, J., Soukup, P., \& Simonová, J. (v tisku). Ověření konceptu akademické marnosti v českém středním vzdělávání. Sociologický časopis / Cz̧ech Sociological Review.

Straková, J., Tomášek, V., \& Palečková, J. (1998). Tretí mezinárodni výzkum matematickébo a prírodovédnébo vadèláni - Soubrnné výsledky žákủ poslednich ročnikư stredních škol. Výzkumný ústav pedagogický.

Thapa, A., Cohen, J., Guffey, S., \& Higgins-D’Alessandro, A. (2013). A review of school climate research. Review ofEducationalResearch, 83(3),357-385.https://doi.org/10.3102/0034654313483907

Uline, C., \& Tschannen-Moran, M. (2008). The walls speak: the interplay of quality facilities, school climate, and student achievement. Journal of Educational Administration, 46(1), 55-73. https://doi.org/10.1108/09578230810849817

Van de Werfhorst, H. G., \& Mijs, J. J. (2010). Achievement inequality and the institutional structure of educational systems. A comparative perspective. Annual Review of Sociology, 36(1), 407-428. https://doi.org/10.1146/annurev.soc.012809.102538

Van Houtte, M. (2004). Tracking effects on school achievement: a quantitative explanation in terms of the academic culture of school staff. American Journal of Education, 110(4), 354-388. https://www.jstor.org/stable/10.1086/422790

Van Houtte, M. (2016). Lower-track students; sense of academic futility: selection or effect? Journal of Sociology, 52(4), 874-889. https://doi.org/10.1177/1440783315600802

Van Houtte, M., \& Stevens, P. A. J. (2008). Sense of futility: the missing link between track position and self-reported school misconduct. Youth and Society, 40(2), 245-264. https:// doi.org/10.1177/0044118X08316251

Van Houtte, M., \& Stevens, P. A. J. (2010). The culture of futility and its impact on study culture in technical/vocational schools in Belgium. Oxford Review of Education, 36 (1), 23-43. https://www.tandfonline.com/doi/abs/10.1080/03054980903481564

Van Houtte, M., \& Stevens, P. A. J. (2015). Tracking and sense of futility: the impact of between-school tracking versus within-school tracking in secondary education in Flanders (Belgium). British Educational Research Journal, 41(5), 782-800. https://doi.org/10.1002/ berj. 3172

Wang, M. T., \& Degol, J. L. (2016). School climate: a review of the construct, measurement, and impact on student outcomes. Educational Psychology Review, 28(2), 315-352. https://doi. org/10.1007/s10648-015-9319-1

Zullig, K. J., Koopman, T. M., Patton, J. M., \& Ubbes, V. A. (2010). School climate: Historical review, instrument development, and school assessment. Journal of Psychoeducational Assessment, 28(2), 139-152. https://doi.org/10.1177/0734282909344205 


\section{Kontakt na autory}

Jana Straková

Ústav výzkumu a rozvoje vzdělávání, Pedagogická fakulta, Univerzita Karlova

E-mail: jana.strakova@pedf.cuni.cz

Jaroslava Simonová

Ústav výzkumu a rozvoje vzdělávání, Pedagogická fakulta, Univerzita Karlova

E-mail: jaroslava.simonova@pedf.cuni.cz

\section{Corresponding authors}

Jana Straková

Institute for Research and Development of Education, Faculty of Education, Charles University

E-mail: jana.strakova@pedf.cuni.cz

Jaroslava Simonová

Institute for Research and Development of Education, Faculty of Education, Charles University

E-mail: jaroslava.simonova@pedf.cuni.cz 


\section{Př́loha 1}

Tabulka 1

Konstrukt akademické marnosti

\begin{tabular}{|c|c|c|c|c|}
\hline & & Průměr & $\mathrm{SD}$ & $\mathrm{ICC}^{13}$ \\
\hline $\mathrm{MU}$ & \multicolumn{4}{|l|}{$\begin{array}{l}\text { Pro kolik učitelů v této škole platí následující tvrzení? } \\
\text { (1 - všichni, } 2 \text { - většina, } 3 \text { - někteří, } 4 \text { - žádní) }\end{array}$} \\
\hline MU1 & Je jim jedno, jaké mají žáci známky & 2,88 & 0,66 & 0,12 \\
\hline MU2 & Je jim jedno, jaké mají žáci problémy mimo školu & 2,44 & 0,86 & 0,09 \\
\hline MS & \multicolumn{4}{|c|}{$\begin{array}{l}\text { Pro kolik z Tvých spolužáků v této škole platí následující tvrzení? } \\
(1-\text { všichni, } 2 \text { - většina, } 3 \text { - někteří, } 4 \text { - žádní) }\end{array}$} \\
\hline MS1 & Je jim jedno, když mají špatné známky & 2,72 & 0,65 & 0,14 \\
\hline MS2 & Ztrapňují spolužáky, kteří se dobře učí & 3,53 & 0,70 & 0,15 \\
\hline MS3 & $\begin{array}{l}\text { Neučí se tak dobře, jak by mohli, protože nechtějí, } \\
\text { aby je kvůli tomu spolužáci ztrapňovali }\end{array}$ & 3,70 & 0,62 & 0,13 \\
\hline MZ & \multicolumn{4}{|c|}{$\begin{array}{l}\text { U následujících výroků vztahujících se k této škole uved', } \\
\text { nakolik s nimi souhlasíš. } \\
\text { (1- rozhodně souhlasím, } 2 \text { - spíše souhlasím, } 3 \text { - spíše nesouhlasím, } \\
4 \text { - rozhodně nesouhlasím) }\end{array}$} \\
\hline MZ1 & $\begin{array}{l}\text { Žáci jako já nemají šanci, že budou v životě dělat, } \\
\text { co by chtěli }\end{array}$ & 3,03 & 0,78 & 0,10 \\
\hline MZ2 & Žáci jako já mají špatné známky, i když se snaží & 2,95 & 0,74 & 0,14 \\
\hline MZ3 & V této škole mají žáci jako já smůlu & 3,09 & 0,75 & 0,11 \\
\hline MS4 & $\begin{array}{l}\text { Abys měl/a v této škole dobré známky, musíš mít } \\
\text { štěstí }\end{array}$ & 3,00 & 0,78 & 0,10 \\
\hline MS5 & $\begin{array}{l}\text { Nemá smysl se v této škole snažit, lidé jako já stejně } \\
\text { nikdy nezískají dobrou práci }\end{array}$ & 3,45 & 0,71 & 0,13 \\
\hline
\end{tabular}

13. Koeficient vnitrotř́dní korelace - ukazuje, jaký podíl rozdílů v dané proměnné je možno vysvětlit rozdíly mezi třídami. Hodnoty koeficientu ukazují, že v př́ípadě jednotlivých položek akademické marnosti je možno rozdíly mezi tř́́dami vysvětlit $9-15 \%$ rozdílů $\mathrm{v}$ individuálních hodnotách. $\mathrm{V}$ př́padě výsledné hodnoty akademické marnosti (faktorový skór) vysvětlují rozdíly mezi tř́́dami $20 \%$ individuálních rozdílů. To znamená, že jednotlivé tř́idy se v tomto ukazateli liší a o akademické marnosti má smysl uvažovat na úrovni třídy jako o proměnné charakterizující klima třídy (kultura akademické marnosti). 


\section{Př́loha 2}

Tabulka 2

Deskriptivni statistiky promènných využitých ve strukturnim modelu

\begin{tabular}{|c|c|c|c|c|c|c|c|}
\hline & & & & \multicolumn{2}{|c|}{ nevážený } & \multicolumn{2}{c|}{ vážený } \\
\hline & $\mathrm{N}$ & Minimum & Maximum & Průměr & SD & Průměr & SD \\
\hline ses & 2641 & $-3,17$ & 1,55 & 0,01 & 1,00 & $-0,28$ & 1,02 \\
\hline mat1 & 2641 & 0,00 & 1,00 & 0,66 & 0,24 & 0,57 & 0,24 \\
\hline mat3 & 2641 & 0,00 & 1,00 & 0,39 & 0,18 & 0,33 & 0,18 \\
\hline cj1 & 2641 & 0,00 & 1,00 & 0,67 & 0,18 & 0,61 & 0,19 \\
\hline cj3 & 2641 & 0,00 & 1,00 & 0,74 & 0,17 & 0,68 & 0,19 \\
\hline am & 2641 & $-1,24$ & 0,80 & 0,03 & 0,28 & $-0,01$ & 0,29 \\
\hline G & 2641 & 0,00 & 1,00 & 0,50 & 0,50 & 0,26 & 0,44 \\
\hline SES & 2641 & $-1,59$ & 1,13 & 0,01 & 0,63 & $-0,28$ & 0,63 \\
\hline MAT1 & 2641 & 0,17 & 0,93 & 0,66 & 0,19 & 0,57 & 0,20 \\
\hline CJ1 & 2641 & 0,16 & 0,85 & 0,67 & 0,13 & 0,61 & 0,13 \\
\hline AM & 2641 & $-0,30$ & 0,33 & 0,03 & 0,12 & $-0,01$ & 0,13 \\
\hline
\end{tabular}


